\title{
Incorporating Folk Belief into National Heritage: The Interaction between Ritual Practice and Theatrical Performance in Xiud Yax Lus Qim (Yalu wang) of the Miao (Hmong) Ethnic Group
}

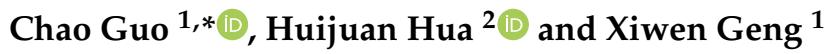 \\ 1 Department of Chinese (Zhuhai), Sun Yat-sen University, Zhuhai 519082, China; gengxw@mail2.sysu.edu.cn \\ 2 School of Performing Arts, University of Otago, Dunedin 9054, New Zealand; \\ huijuan.hua@postgrad.otago.ac.nz \\ * Correspondence: guoch28@mail.sysu.edu.cn
}

check for updates

Citation: Guo, Chao, Huijuan Hua, and Xiwen Geng. 2021. Incorporating Folk Belief into National Heritage:

The Interaction between Ritual

Practice and Theatrical Performance in Xiud Yax Lus Qim (Yalu wang) of the Miao (Hmong) Ethnic Group Religions 12: 899. https://doi.org/ $10.3390 /$ rel12100899

Academic Editor: Xiaohuan Zhao

Received: 29 September 2021

Accepted: 15 October 2021

Published: 19 October 2021

Publisher's Note: MDPI stays neutral with regard to jurisdictional claims in published maps and institutional affiliations.

Copyright: (c) 2021 by the authors. Licensee MDPI, Basel, Switzerland. This article is an open access article distributed under the terms and conditions of the Creative Commons Attribution (CC BY) license (https:/ / creativecommons.org/licenses/by/ $4.0 /)$.

\begin{abstract}
Xiud Yax Lus Qim or Yalu wang 亞魯王 (Ode to the King Yalu) is a type of oral performance inherited verbally and transmitted orally by dongb langf (donglang 東郎, chanters of Yalu wang) at funerals and festive occasions. As one of the most representative cultural sets of the Miao (Hmong) ethnic group located in southern China, Yalu wang is embedded in Miao sorcery beliefs and practices, and serves as a vehicle to unite the community and maintain the identity of the ethnic group. However, since Yalu wang was "discovered" as a heroic epic by scholars in 2009 and entered the government's "List of National Intangible Cultural Heritage" two years later, different agencies have been vying to appropriate its cultural resources. Not only do local government authorities use it as a tourist attraction, stage performances have also produced various versions of Yalu wang to portray an emblem of what are presumed to be "authentic Miao cultures". This article explores the interactive relationship between Miao sorcery and folk traditions in the oral performance of Yalu wang and their enactment and re-enactment in theatrical performances under the aegis of a state-endorsed tourism policy. In so doing, the discussion sheds new light on the bidirectional dynamics that not only remold the style of performing culture, but also facilitate religious synthesis.
\end{abstract}

Keywords: China; Xiud Yax Lus Qim (Yalu wang); Miao (Hmong) ethnic group; oral performance; ritual practice; sorcery and witchcraft; collective memory; cultural heritage; state presence

\section{Introduction}

Xiud Yax Lus Qim (Yalu wang 亞魯王, literally "Ode to the King Yalu") is a type of oral performance and ritual practice associated with traditional Miao (Hmong) funerals and festivals in southern China. In approximately 20,000 lines, this story narrates the creation of the world and the history of Miao ancestors, centering on the life trajectory of the eighteenth king, Yalu-his success, defeat, exodus, and finally leading a Miao renaissance. ${ }^{1}$ Yalu wang is circulated in numerous subdialect groups of the Miao ethnic group, but in most cases it appears as scattered fragments and none are as well preserved as that performed by the Mashan subdialect group. The Mashan area is centered in the city of Anshun, Ziyun county in Guizhou province, and also includes parts of Wangmo, Changshun, Luodian, Huishui, and Pingtang counties (See Figure 1). The better preservation of Yalu wang in this area can be attributed to its geographical location in a typical karst topography, which for centuries has left its people in a relatively isolated state (Tang 2010, p. 89). As cultural contacts with the outside world have historically been extremely limited, many traditional customs, including the oral performance of Yalu wang and its related ritual practices, are well preserved and are still practiced in a more authentic way. 


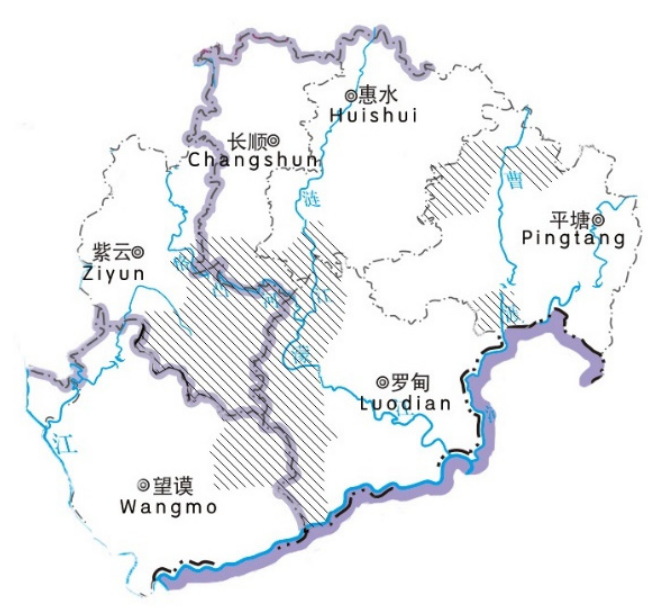

Figure 1. Range of the Mashan Region.

Official discourses on Yalu wang first emerged in 2009, soon after it was "discovered" by Yu Weiren 余未人 (b. 1942), the then deputy chair of the Chinese Folk Literature and Art Association (CFLAA), through ethnographic fieldwork in southwestern Guizhou. Following the efforts by Chinese Communist Party (CCP) cadres to collect folkloric literature that was launched in Yan'an in the 1940s, and extensively promoted after the foundation of the People's Republic of China (PRC) in 1949, earlier scholars of Yalu wang quickly defined the text as a "heroic epic" (yingxiong shishi 英雄史詩) dating back to 2033-1562 BCE. They made parallels with other well-known ethnic epics, such as those associated with the Tibetan cultural hero King Gesar, the Jangar story of the Mongols, and Manas of Kyrgyz ethnic groups (Yalu wang, pp. I-188). ${ }^{2}$ Later, Chao Gejin 朝戈金 (Chao 2012) redefined Yalu wang as a "composite epic" (fuhe shishi 複合史詩) since it combines “the characteristics of the three sub-types of epics-heroic epic, creation epic, and migration epic-that circulate in China". Chao's argument broadens the definitional aspects of Yalu wang, but is still confined to the specific field of the epic.

It is salient to argue that the official discourses that define Yalu wang as an epic (in any form) obviously suggest a type of bias from a literary perspective. With more scholars in other disciplinary fields showing an interest in Yalu wang, its ritual aspects have more recently begun to draw greater scholarly focus. Yang Liu 楊柳 (Yang 2016, p. 147), for example, points out that Yalu wang is commonly used for the ritual practice of jangz ghad (kailu 開路, literally "paving the way") at traditional Miao funerals. In the same vein, Xu Xinjian 徐新建 (Xu 2014, p. 81) argues that Yalu wang is not limited to a "heroic epic" but is a "combination of oral and ritual performances". As a type of ritual practice, Yalu wang uses oral performance as the vehicle for the Miao sorcery belief in ancestral spirits. Because Yalu wang is a ritualized performance at Miao funerals, some scholars take Yalu wang to be a cultural phenomenon that conveys the cognitive aspects of the ethnic group, and refer to the entire ritual practice of Yalu wang as "Yalu culture" (Tang 2012, p. 49; Zhang and Peng 2013, p. 83).

Drawing on the theoretical framework of E.E. Evans-Pritchard, Clyde Kluckhohn, and John Middleton, Zhao Xiaohuan 趙隢寰 (Zhao 2013, pp. 134-35) sheds light on three complementary patterns in the study of wugu sorcery (or wu-shamanism)-loosely rendered as "black magic" —in China: (1) The explanatory, which uses witchcraft to account for misfortunes; (2) The functionalist, which resorts to witchcraft as a means to release unbearable emotions and as a form of social control; (3) The structural, which is concerned with how witchcraft reflects tensions between different social groups and how it is related to the overall social structure. Confirming that Yalu wang is central to the ritual acts embedded in the sorcery beliefs of the Miao, the discussion here examines it within the context of funerals. It takes as a starting point Jack Goody's denial of Durkheim's well-known claim of the "dichotomy of the universe into the sacred and the profane" (Goody 2010, p. 16), where Goody goes on to define ritual as "a category of standardized behaviour (custom)" 
(ibid., p. 36). Understood as a manifestation of Goody's category of custom, Yalu wang can be said to be "the sum-total of certain rules and cultural achievements, [it] embraces ... both Profane and Sacred" (Malinowski 1948a, p. 41). Based on the embrace of the sacred and the profane, we observe in Yalu wang at least two layers of Miao philosophy. First, the ritual acts of Yalu wang are built on the Miao belief in wugu sorcery, which, as Goody (2010, p. 36) suggests in a different context, is a type of irrational or nonrational behavior used to handle the affairs after death. Second, it echoes what Richard Schechner (1993, p. 4) refers to as "the efficacy of ritual acts", which, in our case, is achieved by the oral performance of Yalu wang. In terms of ritual, then, the performance of Yalu wang fulfils its functions on the unity and identity of the ethnic group (ibid., p. 20).

Within the terms of Zhao's threefold framework, the analysis in Section 2 elaborates on the content of Yalu wang and the role of dongb langf (donglang 東郎, chanters of Yalu wang), disclosing their function as the agents bridging the mourners and Miao ancestors at funerals. Section 3 deepens the examination of the cultural connotations behind Yalu wang, discussing how the Miao belief in sorcery functions to frame a common history and collective memory that help unite the community and maintain Miao identity in Mashan. Section 4 looks at how this form has dealt with a more intrusive state presence over the past decade, as Yalu wang is increasingly and inevitably involved in tensions that have emerged between the local ethnic community, the cultural elite, and state authorities. Bereft of localized features as a manifestation of ethnic knowledge, Yalu wang has become a statesanctioned form of "cultural heritage" and a touristic spectacle. The state's endorsement certainly secures resources for its protection and promotion, and yet the engagement with state power and local government also means a certain kind of disfranchising of Yalu wang, a situation that leads to a new and pressing need to retain its traditional forms and cultural connotations in the face of dynamic processes of modernization that carry within them both secularization and urbanization.

The data used in this article come from a research trip to Ziyun, Guizhou, in 2021 and fieldwork reports by other scholars, including observations on Miao funerals and interviews with dongb langf (Yu 2011; Cao et al. 2012). For convenience, the texts of Yalu wang cited here are taken from an edition titled Xiud Yax Lus Qim, collected by the CFLAA and published by the Zhonghua Book Company (CFLAA 2011). ${ }^{3}$ Using this version for reference does not imply that it can be considered a standardized or definitive form of the text. In fact, there is no single authoritative text; since Yalu wang is transmitted orally, the chanting of which is relatively flexible as long as it follows a "main narrative". Within this framework, not only do different individuals have the freedom to alter details, the same dongb langf can also include ad lib or improvised elements to vary his performances.

\section{Yalu Wang and Dongb Langf at Funeral Scenes}

Chronologically narrated, the oral performance of Yalu wang consists of three major topics-Xiud yangb luf chef (genyuan 根源, ancestral origins), Xiud yangb luf qif (shengping 生平, life stories), and Langb bangb suob (puxi 譜系, the offspring) of Yalu, and finally the chanting comes to the family lineage of the deceased. It can be further subdivided into 11 major parts (CFLAA 2011; Cai 2019, p. 40): ${ }^{4}$

Part 1. Lines 1-1176: Creation of the world by ancestral immortals;

Part 2. Lines 1177-1344: Childhood stories of Yalu;

Part 3. Lines 1345-2870: Battle of Naf Njinb and Pel Jinb. Yalu defeats King Lus Wox, former subordinate of Yalu's father Haed Xix Wus, seizing his land Naf Njinb and Pel Jinb; Part 4. Lines 2871-4020: Battle of the Dragon's Heart. Yalu kills a dragon and obtains its heart. His elder brothers, Saem Yangd and Saem Nblam, are jealous and launch a war. At first, they are defeated by Yalu, but later they use Yalu's consorts, Bob Nim Sangd and Bob Nim Luf, to seize the dragon's heart. Without the dragon's heart, Yalu is defeated and driven away from his territory; 
Part 5. Lines 4021-5174: Battle of Salt Wells. Yalu flees and leads his followers to Blak Jongt Yind and finds salt wells there. Saem Yangd and Saem Nblam feel jealous and launch another war. Yalu has to lead his followers across the river to find new places to settle;

Part 6. Lines 5175-8086: Exodus. Yalu leads his followers to flee across 30 places, and finally takes refuge at Heid Buf Dok's kingdom;

Part 7. Lines 8087-9254: Taking Heid Buf Dok's kingdom by strategy. Yalu and Heid Buf Dok have a duel of wits for dominance over the kingdom. Yalu defeats Heid Buf Dok, drives him off, and takes over his land;

Part 8. Lines 9255-10,819: Reconstructing the new kingdom. Yalu leads his followers to construct his new territory, creates the sun and the moon, and orders his 12 sons to conquer 12 lost places so that these places would inherit the Yalu family lineage;

Part 9. Children of Yalu;

Part 10. Grandchildren of Yalu;

Part 11. Family lineage of the deceased.

Due to successive defeats and the forced exodus of Yalu and his clansmen, the oral performance of Yalu wang is full of melancholic and grief-stricken motifs, intended deliberately to agitate the collective and affective memory of its audiences. For instance, after the defeat at the Battle of the Dragon's Heart, the text is replete with images of suffering and resilience (CFLAA 2011, lines 3977-3984):

Yax Lus jex meinl hah doud (Yalu rides on horseback)

Yax Lus zod kom hah hlongb (Yalu wears black iron footwear)

Yax Lus deib buf dongb nyid lid luok nid lid luok (Yalu's children cry, boo-hoo boo-hoo)

Yax Lus deib buf waf nyid lid luf nid lid luf (Yalu's babies cry, waah-waah waah-waah)

Yax Lus njengs soab angt fub lwf (Yalu burns down his homeland, taking field rations along the way)

Yax Lus njengs rongl angt xongm lwf (Yalu breaks apart his kingdom, taking glutinous rice on a long journey)

Yax Lus jongx buf lwf hud heih (Taking his sorrowful clansmen, Yalu sets out on a long road) Yax Lus jongx buf lwf heid hul (Taking his heartbroken followers, Yalu sets out on a long journey)

His two consorts, Box Nim Sangd and Box Nim Luf, who are cheated by Saem Yangd and Saem Nblam, and whose actions lead to Yalu's defeat, voluntarily bring up the rear in order to pay witness to their transgressions (CFLAA 2011, lines 4003-4006):

Box Nim Sangd deib ntox lah meik rum lah qengl (Box Nim Sangd's blade becomes blunt and she is tired)

Box Nim Luf deib mud lah lod rum lah qengl (Box Nim Luf's spear is broken and she is exhausted) Box Nim Sand lah hol zad pwol nyod (Box Nim Sangd falls in a pool of blood)

Box Nim Luf lah hol zad pwl songx (Box Nim Luf falls on a pile of bones)

The circular, repetitive structure of these lyrics generates a sense of deep sorrow, which is further enhanced by the mournful melody of the chanting. Generally, the melody of Yalu wang simply consists of the notes $m i, l a$, and $m i^{2}$, and each phrase ends with $l a$, either as half notes or crotchets. This conforms to the $y u$ mode ( $y u$ diaoshi 羽調式) in the gongche notation (gongche pu 工尺譜) method of traditional Chinese music that uses characters to represent notes. The tonic of the $y u$ mode melody, $l a$, creates a minor mode or scale which is often used to convey sentimental and sorrowful emotions in Chinese music-for instance, in The Butterfly Lovers (Liang Zhu 梁祝), The Moon over a Fountain (Erquan yingyue 二泉映 月), and Autumn Moon over Han Palace (Hangong qiuyue 漢宮秋月). The solemn timbre of the drum and lusheng 蘆笙 (a bamboo wind instrument with multiple pipes fitted with free reeds), two typical instruments used for Miao ceremonies and festivals to mediate between the ritual professionals and ancestral spirits, also adds to the mournful emotions of the chanting.

When a Miao dies, their family members fire rifles into the air as a way of signaling their mourning, and then deliver messages to relatives of the same clan. One day before the scheduled date of the funeral, at least 20 to 30, over 100 at most, relatives come to pay 
respects to the deceased and offer financial support to the bereaved, before listening to the chanting of Yalu wang at the wake (Tang 2010, pp. 92-94; Tang 2012, p. 49). These funerary rituals are not only confined to China. In the Hmong community in the United States, for example, what is referred to as a "traditional full-service funeral" is still partly preserved (Xiong et al. 2020, pp. 2-3, 7-8). ${ }^{5}$ While the details of a Miao funeral may vary according to the cause of death and economic status of the deceased, Yalu wang is the constant core that is chanted in turn by a group of four to eight dongb langf at the jangz ghad ritual, which often lasts from the sunset of the funeral ceremony to the following dawn when relatives carry the coffin onto the mountain for burial. The funeral scene suggests dongb langf's identity as a type of ritual professional, whose mana, or communicable supernatural power, is not an endowment, but comes from "reference to ancestors and culture heroes" (Malinowski 1948a, p. 55) - in our case, the ability to chant the story of Yalu. Among their number are "big dongb langf" and "little dongb langf", categorized as such by the amount of Yalu wang they have learned. An extremely experienced big dongb langf, who is able to chant the full Yalu wang, is a necessity for funerals, and is for this reason often considered to be the elder in local society (Yu 2014, p. 304).

Another type of shaman-like ritual professional, other than dongb langf, is bot muf (baomu 寶目). Only able to chant fragments of Yalu wang (Yu 2014, p. 303), they primarily use the words as curses in exorcising or divining witchcraft (Yang 2015, p. 77; Tang 2012, p. 48). The identities of dongb langf and bot muf sometimes overlap: dongb langf can perform bot muf's exorcising and divining roles, but bot muf cannot preside over funeral rituals in place of dongb langf. Further, dongb langf commonly receive no payment for their performance at funerals, and are only given "half or one kilo of meat, a few kilos of rice, and some glutinous rice" (Xu 2011b, p. 270) as a present; meanwhile, bot muf often receive payment for exorcising or divining witchcraft. Currently, however, the host family also reimburses dongb langf's work in the form of a cash renumeration. Around 2010, the rate of each dongb langf in Zongdi was 120 CNY (Tang 2012, p. 55). ${ }^{6}$

\section{Cultural Connotations behind the Performance of Yalu wang}

As shown above, while Yalu wang is defined by folkloric scholars as a heroic epic, this fails to make sense of its central presence at traditional Miao funerals. The Miao vernacular refers to the performance of Yalu wang as "angt Yax Lus" (zuo Yalu 做亞魯, literally "doing Yalu"). This cultural context means that Yalu wang is not limited to an oral form of folkloric literature. An equally, if not more, important aspect is that the oral performance of Yalu wang has to be understood as an entire ritual practice manifesting local knowledge. What, then, is the function of Yalu wang, and in what way is this function realized from the emic point of view?

Yalu wang contains two related cultural connotations which are located at different layers of Miao cognition. Drawing on Erving Goffman's (1959, pp. 106-40) theory of interaction ritual, discourses on the cultural function of Yalu wang often stand out on the "front stage", while wugu sorcery, as the schemata of Miao belief, hides in the "back stage". As Mary Douglas (2001, p. 65) puts it, "Ritual focusses attention by framing, it enlivens the memory", while Bronislaw Malinowski (1948a, p. 64) suggests that ritual "unchain[s] the powers of the past and cast[s] them into the present". The mortuary routine performed by dongb lang $f$ creates a liminality that juxtaposes the existence of Yalu (the past) and mourners (the present). Just like Confucian rites that draw on emotive criteria to influence reality (Kertzer 1988, pp. 13-14), the oral performance of dongb langf forms and reinforces a shared cultural memory at the funeral scene, on the basis of the Miao's common identity as Yalu's offspring. Therefore, the history of Yalu is never a dead one. On the contrary, it represents the Miao's cognition of the external world and forms an ethnic spirit of the group which is, in Malinowski's (1948b, pp. 102-3) designation, "a statement of a bigger reality still partially alive", and which "rule[s] the social life".

In this way, Yalu wang interweaves a "commonwealth" in the Miao ethnic group by "keeping up the memory of its kinship by means of common ceremonies in common places 
of worship" (Tönnies 2001, p. 240). How, then, does Yalu wang successfully convey and sustain this collective memory of the group? Key to this function are the interactions between dongb langf and mourners based on the oral performance in funerary services as a means of ritualizing memory and kinship. By means of specific and repeated oral performances of Yalu wang at funeral scenes, this ritual practice is what Paul Connerton (1989, p. 14ff.) refers to as a form of "historical reconstruction", a mnemonic means of performativity that serves to confirm and reinforce the Miao's collective memory of what is believed to have taken place in history. In this sense, the reminiscent reiteration of Yalu as a deified ancestor and cultural hero at funeral scenes unites the Miao community as an ethnic group and maintains this identity by interweaving emotional interaction and cultural consensus among all the individuals as Yalu's offspring. This emotive agitation is preeminently important for the legitimacy of an ethnic group or cultural community that may be being hollowed out or threatened by decline. As a representation of Miao ethnic culture, Yalu wang, as an oral textual artifact, is likely to have become a condensed manifestation of that culture. This caters to the necessity to articulate the Miao's "otherness" in terms of both geographical and geopolitical issues, as a means to maintain their distinctiveness since the time they dwelled in the barren lands of Mashan during the Ming and Qing eras.

"Public mise en scène" or "collectiveness of performance" are central to the ritual of Yalu wang (Malinowski 1948a, pp. 48-49). In funeral scenes, dongb langf and relatives of the deceased are not in a one-sided "performer-audience" matrix. Drawing on what Erika Fischer-Lichte (2008, p. 43) defines as "the transformative power of performance", all those present at the funeral are emotionally engaged in a "chain reaction". The Miao funeral is thus a field of performativity, where relatives of the deceased cry out of grief to the oral performance of dongb langf, who, in return, feel moved and sometimes become tearful due to the mourning of relatives that adds to the solemnity of the ritual practice. Yang Guangwen 楊光文 (b. 1958) and Chen Xinghua 陳興華 (b. 1945) both have experienced crying while chanting due to the influence of relatives, and Chen even exhorts them not to cry, as he would be too sorrowful to perform the ritual (Cao et al. 2012, p. 399; Tang and Ma 2015, p. 72). Therefore, the mutual affect of all parties in the performance plays a central role to the advent of Yalu in the secular realm, and funeral participation thus reinforces the ties in the clan and the ethnic group.

In particular, the historical construction of Yalu wang enhances the cohesiveness of the Miao ethnic group in two dimensions. On the one hand, the cult of the heroic ancestor Yalu is bound up with the unity of the ethnic group. Part 6, Yalu's exodus, delineates the migration of Yalu after he is defeated by his older brothers Saem Yangd and Saem Nblam in the Battle of Salt Wells, and this part is formed from the repetition of one passage (CFLAA 2011, lines 5175-5178):

Yax Lus jex meinl hah doud (Yalu rides on horseback)

Yax Lus zod kom hah hlongb (Yalu wears black iron footwear)

Yax Lus deib buf dongb nyid lid lok nid lid lok (Yalu's children cry, boo-hoo boo-hoo) Yax Lus deib buf waf nyid lid lul nid lid lul (Yalu's babies cry, waah-waah waah-waah)

Part 6 repeats this formulaic passage 30 times, each consisting of 78-80 lines of lyrics, with only the names of places differing (for example, Had Rongl Raen Nogh, and Had Rongl Raen Lim). It takes up a total of 2911 lines-over a quarter of the entire text. The circular structure of this passage generates a sense of vastness and vicissitude, and as such the shared history of encountering and overcoming adversity and suffering interweaves a type of unity among the Miao as Yalu's offspring. Furthermore, the cohesiveness is achieved by the clan's sense of shared history. Part 11 of Yalu wang, the family lineage of the deceased, is a one-hour element in which a dongb lang $f$ chants the Miao names of the clan ancestors for as many as 30 generations (Yang 2011, p. 249; Tang 2012, p. 50; Yang 2015, p. 77). As a Miao custom, the son inherits the last character of his father's name as the first character of his own name. In this way, Yalu wang locates an individual in the blood network of his clan. 
As the dongb langf Liang Darong 梁大榮 (b. 1952) claims, Yalu wang functions to "help his clansmen to find their origins" (Xu 2011b, p. 263).

In extensive interviews, dongb langf's belief in wugu sorcery frequently comes to the fore. This deviates from the argument advanced by Malinowski (1948a, p. 43) of the cultural expectation of funerary rites to maintain "the bond of union between the recently dead and the survivors", which is "of immense importance for the continuity of culture and for the safe keeping of tradition". In fact, Yalu wang is directed precisely at the Miao's fears and doubts in the face of death. In short, it expresses the hope of salvation and immortality (ibid., p. 42). The oral performance of Yalu wang is therefore understood as a way that dongb langf exert their communicable supernatural power to direct the deceased to take a journey back to their lost home, as is well reflected in the name of the ritual jangz ghad, which means "paving the way". Therefore, before the funeral takes place, relatives of the deceased must prepare "straw shoes, food and drink, bow and arrows, and a rattan helmet" (Ding 2014, p. 25), which are obviously necessities for a voyager. These can only be sent to the deceased via dongb langf's divine power as the agents between the Miao ancestors and the living.

Dongb langf often believe that their supernatural power comes from enacting Yalu wang. While there is no shamanic trance for the possession of Yalu's spirit, dongb langf temporarily assume the identity of Yalu during the jangz ghad ritual, where they must wear formal blue clothing and a broad-brimmed straw hat to stand in front of the coffin, while holding a long saber. This costume represents the historic attire of Yalu during war campaigns - the formal dress imitates his coat of armor, and the straw hat represents his helmet (Xu 2011a, p. 143; Yang 2014, p. 245). In Miao terms, death is either referred to as lwf bjied (huijia 回家, literally "returning to the homeland") or jinb xiangb (jinxiang 育 相, literally "assuming the position of prime minister") (Ma 2014, p. 94). These two terms are somewhat intertextual in that they echo the closing sections of Yalu wang, where Yalu dispatches his sons to seize their lost home-Naf Njinb, Pel Jinx, Nax Buf, and Mix Gux. As the oral performance goes (CFLAA 2011, lines 9499-9510):

Yax Lus lul jongx qws juf box nyab hoh (Yalu leads his 70 spouses)

Yax Lus lul jongx qws juf box nyab lud (Yalu leads his 70 consorts)

Jong $x$ wes lwf paed nong $x$ (Leading them to burn millet)

Jong $x$ wes lwf paed nbaex (Leading them to burn bran)

Jong $x$ wes lwf paed qws bat nboh njux (Leading them to burn 700 nboh njux) ${ }^{7}$

Jong $x$ wes lwf paed qws juf meid dwd (Leading them to burn 70 straw shoes)

Yax Lus blaeb mud qws bat lwf qws nongh diah (Yalu throws 700 spears in the direction where the sun rises)

Yax Lus blaeb neind qws juf lwf qws nongh mos (Yalu shoots 70 arrows in the direction where the sun sets)

Yax Lus buf pef qws juf nblah nzal rangx lwf qws nongh diah (Soldiers of Yalu beat bronze drums 70 times in the direction where the sun rises)

Ndangd ndongx ndangd daeb ndangd dwf hlah (Shaking Heaven and Earth, taratatat, taratatat) Yax Lus jangk plod guf baeb rah gongb dwf hlwb lwf qws nongh mos (Generals of Yalu blow white horns in the direction where the sun sets)

Ndangd ndongx ndangd nzwl ndangd dwf wom (Shaking Heaven and Earth, tarantara, tarantara)

Burning these items is similar to offering sacrifices at funerals, while beating drums and blowing horns are similar to playing solemn funeral music for fallen soldiers. Therefore, in the context of Yalu wang, funerals and campaigns are one and the same. Each funeral restores the scene of a campaign where dongb langf, now in the role of Yalu, promote the deceased as the prime minister and order them to return to their ancestral wonderland.

While most dongb langf's front stage narratives suggest that their costume is an imitation of Yalu, to highlight their function of maintaining Miao identity and uniting the community as an ethnic group, the back stage expressions of some dongb langf present a powerful affirmation of the belief in witchcraft during funeral rites. According to Tang Na's 唐娜 (Tang 2012, p. 51) fieldwork report, dongb langf's costume is one in which they 
arm themselves with "instruments that help separate this world from the world after, such as holding a long sabre, and wearing a straw hat (commonly with an ear of rice on top of it) and iron shoes. Before chanting Yalu wang, the dongb langf flourishes the sabre around himself as a means to avoid following the deceased to the world after". Another case is the iron shoes. Dongb langf often wear them back to front, and this connotes that they can come "back" afterwards. ${ }^{8}$ Chen Xinghua has said that most dongb langf are afraid to perform the closing session of a jangz ghad ritual where the deceased is sent off on a journey, as they believe if not properly maneuvered the ritual will lead the performer to madness. To separate themselves from the spirit, dongb langf must declare a departure from the deceased, returning to the world of the living from the liminal space of jangz ghad:

I am getting farther away from you. You can hear me but can't see me. I have to tell you this across mountains and rivers: now you have to go to the place you are bound for, but I can't go any farther. Your shoes are made of cloth and straw and can lead to all the places, but mine are made of iron so I can't cross the river. (Tang and Ma 2015, p. 72). ${ }^{9}$

Some dongb langf's narratives of their costumes also question the validity of functionalist front stage arguments of "imitation of Yalu's equipment during war time", and suggest instead the Miao's wugu belief in ancestral spirits. Drawing on the statements of “old-timers", the dongb langf Wei Zhengrong 韋正榮 (b. 1952) declared that “dongb langf did not wear a sabre at jangz ghad ritual". The reason is that:

once, a dongb langf was chanting Yalu wang while the watchmen were slumbering. As he chanted on, the dead suddenly jumped up and chased him ... into the field. He had no place to hide, so had to use straw to cover his head. ... As a result, now dongb langf all wear a straw hat. Later, for fear that this might happen again, dongb langf began to wear a sabre to protect themselves. (Wang 2011b, p. 296)

However, the discrepancy between the varying, or even conflicting, accounts from dongb langf cannot be simplified to a matter of either correct or incorrect; honest or dishonest. Their narratives reflect different levels of cultural connotation in Yalu wang: while most dongb langf suggest that Yalu wang is a condensed ritual central to the ethnic identity of the Miao, few are aware of the historical construction behind this master narrative at the front stage. As part of the Miao's perceptions of the external world, elements of wugu sorcery normally concealed at the back stage may sometimes come to the fore in an unconscious way, hence the "inharmonious voices" that deviate from the master narrative. Furthermore, the narrative of Yalu wang evolves around a fixed main narrative, and details of the chanting are sustained by some formulaic sentences or passages, just like the improvisation of a canovaccio theater form, due to the flexibility of oral performance. However, while the dongb langf Chen Xinghua argues that "[You should] grasp the main body in the first place, and then add content in accordance with the situation" (Tang and Ma 2015, p. 71), others are keen to stress the stability in their oral performance (Cao et al. 2012, p. 144). This "duplicity", where dongb langf delineate Yalu wang as "absolutely inalterable and inviolable", shows their strategy of convincing, the covert reason of which is to maintain the authority of this oral convention and the authenticity of the cultural construction behind it (cf. Malinowski 1948a, p. 49). This is certainly somewhat a result of dongb langf's desire to maintain their mastery as ritual professionals in local communities but also as spiritual agents in Miao culture. However, they are not necessarily aware of the historical construction that is internalized in Yalu wang as a cultural set.

\section{Increased State Presence and the Status of Yalu wang}

Resulting from the successive social and political movements after the foundation of the PRC in 1949, an increased state presence has led to the more aggressive engagement of external forces in the ritual practice of Yalu wang. In the process, where Mashan, once a closed area, was incorporated as an integral part of the Chinese nation-state, the 
traditional cultural apparatus has been progressively disenfranchised by pervasive state power. Not only were the cultural resources that dongb langf once held overshadowed by political power, the cultural connotations of Yalu wang also faced the predicament of appropriation. Specifically, Yalu wang has been denuded of its structural function as a foundational element of cultural memory that had, in the past, secured the identity of the Miao as an ethnic group. It has been engulfed by the transforming sociocultural projects of the state due to the politicization of social life after 1949. From its decline, since the 1950s to its return as "cultural heritage" in the new millennium, Yalu wang has become a dynamic signifier that is constantly narrated and renarrated by the urgent requirements of the state.

As an embodiment of its determination to depart from the maladies of what it perceived as China's morbid, moribund past, the CCP called for "eliminating all ghosts and spirits in feudal superstition", including Yalu wang and Miao funerals. The dongb langf Yang Guangxiang 楊光祥 (b. 1936) claims that, during the Great Leap Forward in 1958, "the leaders in the [People's] Commune did not allow us to perform jangz ghad ritual for the deceased elderly, declaring that leftovers of the old society were not allowed in the new society" (Li 2011b, pp. 277-78). Later, in 1966, the onset of the Cultural Revolution witnessed the intensification of this practice, and the jangz ghad ritual was forbidden: "[Any dongb langf who] violated this was to be denounced in a struggle session (pidou 批鬥)" (Tang and Ma 2015, p. 69). For example, Liao Changhua 廖長華 and Liao Yousheng 廖 友生 were sent to the city to attend a "learning class" (xuexi ban 學習班) of Mao Zedong thought and were only allowed to return home six months later (Gao 2014, p. 371). Tang $\mathrm{Na}$ (Tang 2012, p. 56) describes this tension as "the apex of the conflict between folk belief and state ideology", in which "dongb langf were forced to choose between Yalu wang and Chairman Mao". However, these two choices were not as straightforwardly exclusive as Tang suggests. In fact, folk belief showed a strong sense of malleability and adaptability in the face of state ideology. Secret practices of traditional funerals were frequently performed. Not only would dongb langf venture a performance of Yalu wang, some local party cadres also chose a laissez-faire attitude toward folk belief and considered inspections of ritual practices a mere formality.

The end of the Cultural Revolution did not mean a return to Yalu wang's prior status. Quite the contrary, for rather different structural reasons, it underwent a more serious decline after the launching of the reform and opening by Deng Xiaoping 鄧小平 (1904-1997) in 1978. Due to China's modernizing program, featuring a distinctively Chinese variant of the market economy, the state partially withdrew from people's private lives, while the vigorous pursuit of profits and personal wealth became a new challenge to folk beliefs in local society. In the cultural domain, the homogenizing tendencies of modernity also threatened to remove all differences, ethnic differences included. Since the mid-1990s, young people have left Mashan to become laborers in Guangdong and Guangxi for better pay. According to the dongb langf Yang Baoan 楊保安 (b. 1952), “Very few people come to see us chanting [Yalu wang] now, primarily because there are fewer people in the village. Many young people work outside. Often, at jangz ghad rituals just a few of us-dongb langf-accompany the host family at the wake" (Li 2011a, p. 183).

Before Yalu wang was "discovered" by Yu Weiren in 2009, it had never been interwoven in a more intricate nexus of wider social forces, which would have accelerated its acculturation. The dubious and one-dimensional discourse that presented Yalu wang as an ethnically particular historical epic was in fact a projection on the part of the state to renarrate its core meaning. As noted above, at least five decades before Yu Weiren declared her discovery of the "heroic epic", jangz ghad performed by dongb langf at Miao funerals had already been identified by the CCP and "forbidden", as it was deemed a manifestation of outmoded superstition. The only difference is that, while in the 1950s, jangz ghad was considered a ritual, the central content of jangz ghad, Yalu wang, is now extricated from its integrated ritual practice and is bestowed with a brand-new and more palatable cultural-political label as an "epic" in the corpus of ethnic literature. In 2011, the state added Yalu wang to the "List of National Intangible Cultural Heritage" (DMCNICH 2011, I-118). While 
this approbation secured protection and promotion from the state, this close engagement and indeed oversight of the state turned Yalu wang into a more secularized emblem of the state's cultural confidence. As various official discourses suggest, the state has renewed the historical narrative that the Miao ethnic group does indeed possess an epic genealogy, a noted addition to the treasury of world literature. At the same time, however, this officially sanctioned endorsement deliberately disconnects Yalu wang from its cultural context as a funerary ritual practice that is central to Miao identity formation and maintenance.

This process of silencing is even more evident in the case of the local governments of Ziyun and Anshun, the agencies directly responsible for Yalu wang's protection and promotion. Their foremost concern is Yalu wang's value as a tourist attraction and as a means for generic cultural promotion, ultimately with the instrumental aim of securing economic benefits. After 2011, Yalu wang became a cultural trump card of Anshun, and the official account of the Publicity Department of the CCP Ziyun Committee on WeChat is named "Yalu Ziyun". The form and discourse officially promoting Yalu wang is, in every substantive meaning, a form of disenfranchisement-it was deliberately removed from its traditional context of funerary rites while catering to an outsider audience's voyeuristic curiosity to peep into the lifestyle of so-called “ethnic minorities" (shaoshu minzu 少數民族).

Taking advantage of the "discovery" of the epic, the Ziyun authorities have been focusing on the construction of the Getu River Scenic Area, hidden in the mountains south of Anshun, as its economic engine and cultural showcase. The strategy of the local government clearly shows a desire to rely on Yalu wang as a means of tourist advertising. In May 2018, Ziyun launched a 560 million CNY project called "Yalu Wang City" (Yalu wang cheng 亞魯王城) in Getu, aiming to use Yalu wang to develop its cultural attraction as a form of "ethnic tourism". Yalu Wang City is located at the foot of a mountain, and includes a royal court, a sacred city, and a living area. In October 2018, a burlesque performance of Millennium of Yalu Wang (Qiannian Yalu wang 千年亞魯王) was presented in Yalu Wang City as a tourist attraction three times a day. One other very obvious, and slightly bizarre, manifestation of this "reinvention of tradition" illustrates the primacy of the pursuit of tourist income. Huang Xiaobao 小寶 (b. 1962), a dongb langf and expert in free climbing, has performed at the 108-meter cliff face in Getu since the 2000s (Cao et al. 2012, pp. 337-38). Moreover, in October 2010, the local government of Ziyun first created a connection between Getu and Yalu wang through the "Yalu Wang cultural tourism festival and Getu River rock climbing challenge". As the advertisement suggests, "welcome to the hometown of Yalu wang", Getu now receives official empowerment as the representation of Yalu wang.

What should be clear is that these activities in the name of Yalu wang are merely scattered cultural fragments removed completely from their traditional cultural context of Miao funerals. Yalu wang is historicized, that is, it is bereft of all its deep-seated functions as a historical construction that maintains a distinctive ethnic identity. In 2011, Ziyun county performed a tailor-made program, "Yalu Wang Crosses the Mountain of the Knife and the Sea of Fire" (Yalu wang zhi daoshan huohai 亞魯王之刀山火海), at the ninth National Traditional Games of Ethnic Minorities. As its name suggests, performers climbed a bamboo ladder barefoot, with each rung made of blades. Another group of performers walked across a burning iron plate, also barefoot. While presented in the name of Yalu wang, this performance was not Miao in any shape or form. Technically, the program comes from the Knife-ladder Climbing Festival (Daoganjie 刀杆節) of the Lisu ethnic group (DMCNICH 2006, X-27). The Yalu wang elements were added arbitrarily to the program, which is more of a dazzling acrobatic performance chosen as an emblem for Guizhou in the national pageant.

Even more egregiously, some local performance agencies have distilled the funeral chanting into stage performances which synthetically embrace instrumental music-drum, suona 隕呐 (double-reeded horn), and lusheng — oral/vocal performance, and choreography. With different forms of programs, various agencies are competing for the cultural resources of Yalu wang. Currently, there are two established programs: one is Millennium of Yalu wang and the other is a "choral theater" production titled Yalu wang, which debuted in 
December 2018. These two performances show the different perceptions of two groupsMiao scholars and the (Han Chinese) cultural elite-on what elements in Yalu wang can stand in for the Miao ethnic group.

Elements of traditional resources and tourist attractions coexist in Millennium of Yalu wang. Performed on a temporary stage at the central square of Yalu Wang City, this program is directed by Yang Zhengjiang, who is a dongb langf contributor to the 2011 version of Yalu wang, and currently a cultural cadre of Ziyun. The performance area is divided into three major parts: three dongb langf upstage, six percussionists downstage, and several groups of dancers take turns to perform center stage. Starting from a series of queries into "who am I, where am I from, where are my ancestors, and where is my hometown?" the 20-min program evolves around the main narrative of the Yalu wang stories, from the creation of the world to Yalu's success, love, defeat, exodus, reconstruction, and renaissance of the Miao regime. In each section, dongb langf chant an excerpt from Yalu wang in Miao vernacular, with a narrator summarizing the story in Mandarin Chinese. Generally, this program seizes the cultural context of Yalu wang, following its main narrative to show the Miao ethnic group's remembrance of their hometown. Moreover, while not clarified, in the second scene, "Ritual", a screen behind the dongb langf plays a video of a traditional Miao funeral ceremony, which, to some extent, suggests the original funeral scene of Yalu wang. However, this program is more a theatrical performance than a ritual practice, so it adds showbusiness elements to the chanting of Yalu wang. While it resorts to the acrobatics of knife mountain climbing and fire-eating to attract tourists, other performances are choreographed with reference to Miao dances. For instance, in the scene "Exodus", a performer and a lusheng musician would stand on their heads while performing. This is a fragment absorbed from the Small Flowery Miao (Xiaohua miao 小花苗) ethnic subgroup and their “Little Dance of Migration" (Xiao qianxi wu 小遷徙舞), a dance that also derives from the retreat of Yalu during a battle. Hence, the past is accumulated in the performers' bodies.

In deep contrast to Millennium of Yalu wang, the choral theater production Yalu wang is performed by a chorus of 400 vocalists at Guiyang Grand Theater, after half a decade of collaboration with more than 30 well-known artists. As a project fully funded by the CCP Publicity Department of Guiyang, this choral theater reflects the cultural elite's desire to dominate the discourse of ethnic culture. This theater piece has hardly any melody derived from the chanting of Yalu wang. As the music director Xiao Bai 肖白 and the conductor Fang Ling 方玲 declared, the reason is that folk music (the chanting of Yalu wang) in Ziyun is not representative of the Miao ethnic group, so they used a series of modes and scales distilled from Miao music to create a new melody (Yue 2019). While they argue that the melody is "undoubtedly Miao", it is absurd (and arrogant) to think that a reinvention is more Miao than the Miao culture embodied in Yalu wang. In fact, the vocal performance of this theater piece basically follows the principles of the bel canto lyrical style used in operatic arias and accompanied by an orchestra and chorus. The yu mode of gongche solfège that features sentimental and sorrowful emotions is removed, and in its place now is an epic scene recreated via the timbre of bel canto. The panegyric of "the first music theater of the Miao's epic in China" (ibid.) shows an official endorsement of the cultural elite vying for Yalu wang's cultural resources, which are finally and fundamentally turned into a disconnected, disembodied "heroic epic" in official discourses.

This juxtaposition of the practices of various actors clearly shows a tension between an ethnic legacy as an organic form of local knowledge and the reinvented ethnic heritage by the cultural elite. As the title of a report, "What Can Represent the Miao Ethnic Group?" (ibid.) suggests, the cultural elite believe that they are representatives of ethnic cultures. In this sense, if performance agencies only take fragments of music and theater out of the ritual practice of Yalu wang, the cultural elite's brand-new creation dislodges Yalu wang from an ethnic culture embedded in folk belief and sorcery, relocating it within an acceptable and commercialized framework of state-sanctioned cultural heritage. 


\section{Conclusions}

Originally, Yalu wang was a type of oral performance, a central element of the ritual practices at Miao funeral rites. From an emic point of view, the dongb lang $f$ have divine powers to direct the deceased to the lost home of their progenitors. The content of Yalu wang includes Yalu's role in Miao warfare, their exodus, and the lineage of his offspring. As a cultural artifact, it creates a liminality at funeral scenes that juxtaposes the past and the present, which in turn recreates and reinforces the collective memory through a form of performativity participated in by all. In sum, the Yalu wang funerary rituals serve as a means to maintain ethnic identity and unite the local community. This functionalist framework is built on the Miao's wugu belief that the interactions between the living and ancestral spirits can be properly mediated and controlled by the witchcraft of dongb langf. These two dimensions speak to two layers of the Miao's cognition of the external world, and are both confirmed in the front stage and back stage narratives of dongb langf.

After it was officially "discovered" in 2009, Yalu wang has been woven into the nexus of diverse and sometimes contradictory discourses articulated by various forces that vie for its cultural resources. Even the term "Yalu wang" itself is a new cultural construct. While state observation-and prohibition—of the performance of jangz ghad rituals has been a reality since the 1950s, Yu Weiren's appropriation of the ritual has cleansed it of all elements of sorcery and has redefined it as a straightforward heroic epic. This process is merely one more example of the state-driven epic collection project that has been in train for the past six decades. Yalu wang is therefore endorsed in the official discourse as a gap-filling discovery that has rewritten a historical narrative that previously posited that the Miao have no epic of origins. As we have seen, in 2011, Yalu wang entered the "List of National Intangible Cultural Heritage", which secured financial support for its protection and promotion at the state level. While the state uses Yalu wang as a demonstration of its own cultural confidence, the local government of Ziyun cherry-picks its cultural elements as a tourist attraction to obtain economic benefits or to present Guizhou's "ethnic culture" in national pageants. The fact that some (Han Chinese) artists believe their contemporary performance is more Miao than traditional Miao performances is an example of a desire to seize elements from ethnic cultures in order to develop a commercialized creative industry.

While on the surface all these actions are said to preserve, protect, and promote Yalu wang, in fact they threaten to hollow out Yalu wang from its core cultural context, since few if any of these activities and programs directly mention Yalu wang's function at funeral rites. Either way, the reinvented Yalu wang has lost its meaning in the local community for the Miao, becoming fragments bereft of cultural context. The fate of Yalu wang is representative of the paradoxical status quo of all ethnic cultures in a rapidly globalizing and commodifying China (and we may add elsewhere too). As modernization, urbanization, and secularization ultimately lead to a kind of cultural homogeneity, almost all these ethnic cultural practices, as with Yalu wang, face the plight of erosion, dilution, or even elimination. "Intangible cultural heritage" affords them a means of survival, yet at the cost of being divorced from their cultural contexts. This shift from local knowledge to national/universal culture in fact severs its ties to the ethnic group that gave birth to it.

Author Contributions: Validation, H.H.; data curation, X.G.; writing-original draft preparation, C.G.; writing-review and editing, C.G.; funding acquisition, C.G. All authors have read and agreed to the published version of the manuscript.

Funding: This research was funded by the National Social Sciences Foundation of China, grant number 21CB171.

Conflicts of Interest: The authors declare no conflict of interest.

\section{Notes}

$1 \quad$ Initially "Yalu" was not a person's name but a title that means "old grandfather" or "old ancestor", used as "an honorific title for a prestigious leader". Due to the long use of honorific titles and the difference in Hmong dialects, the meaning of "Yalu" was gradually blurred until it was treated as a person's name (Wu 2012, pp. 34-37). 
2 While some elements of the funeral rituals were likely to have been formed in very early times, the formation of Yalu wang was no earlier than the late first millennium $\mathrm{CE}$, because the Hmong migration only arrived in northwestern Guizhou and northeastern Yunnan around 1000 to 700 years ago (Wu 2012, p. 40).

3 The Romanized writing system used in the 2011 version was created by one of the collectors, Yang Zhengjiang 楊正江, a scholar of Hmong origins in Mashan. The Hmong language has long had only a phonetic system but no written script. In 1956, the survey group of the Chinese Academy of Social Sciences created a Roman alphabet for some dialects and subdialects of the Hmong language, and revised it twice, in 1958 and 1980, but this project did not include the Mashan subdialect. In order to accurately record the text of Yalu wang, Yang Zhengjiang used the 1956 romanization format to create a separate system for the Mashan subdialect, which he then employed for the text of Yalu wang.

4 The 2011 version of Yalu wang only includes the first 10,819 lines of the story. Later sections of Yalu wang narrate the renaissance of the Yalu kingdom and its lineage.

5 While Xiong et al. (2020, p. 8) do not describe the details, "the Show the Way recitation [that] can last for $4-5 \mathrm{~h}$ " is likely the same as the jangz ghad ritual in Mashan. However, due to constraints of time and for financial reasons, there has been a decline in the number of traditional full-service funerals in North America. This suggests a similar plight of acculturation that is also on the rise in Mashan.

6 According to an interview with Wei Laowang 韋老王 (b. 1937), a dongb langf in Zongdi, “the cash payment for each funeral is 160 CNY, plus some rice, meat, wine, and cigarettes, the value comes to a total of 200 CNY" (Cao et al. 2012, p. 138).

$7 \quad$ Nboh njux is a type of dark blue or black cloth decorated by embroidery of motifs of the sun. It is believed to have been Yalu's army flag and is often used to cover the face of the deceased.

8 The iron shoes worn by dongb langf are not really shoes, but the iron blade of a ploughshare.

9 In the narratives of other dongb langf they arrive at a slippery mountain. The dongb langf have to turn back because they cannot climb the mountain in iron shoes (Wang 2011a, p. 158).

\section{References}

Cai, Xi 蔡熙. 2019. Yalu wang de wenxue renleixue yanjiu 亞魯王的文學人類學研究 [Literary Anthropologist Research on Yalu wang]. Kunming: Yunnan University Press.

Cao, Weiqiong 曹維瞹, Yongbin Ma 麻永斌, and Xianyi Lu 盧現藝. 2012. Geshi midang 歌師秘 [Secret Records of Dongb Langf]. In Yalu wang shuxi亞魯王書系 [Book Series of Yalu wang]. Guiyang: Guizhou People's Publishing House.

Chao, Gejin 朝戈金. 2012. Yalu wang: Fuhe shishi de xianhuo anli亞魯王：複合史詩的鮮活案例 [Yalu wang: A Living Case of Composite Epic]. Chinese Social Sciences Today, March 23.

Chinese Folk Literature and Art Association [CFLAA] 中國民間文藝家協會. 2011. Yalu wang亞魯王 [Xiud Yax Lus Qim, or Ode to the King Yalu]. Beijing: Zhonghua Book Company.

Connerton, Paul. 1989. How Societies Remember. Cambridge: Cambridge University Press.

Digital Museum of Chinese National Intangible Cultural Heritage 中國非物質文化遺數字博物館. 2006. Lisuzu daoganjie 族刀杆節. I-188. Available online: http:/ / www.ihchina.cn/Article/Index/detail?id=14970 (accessed on 29 September 2021).

Digital Museum of Chinese National Intangible Cultural Heritage 中國非物質文化遺數字博物館. 2011. Yalu wang 亞魯王. In the Digital Museum of Chinese National Intangible Cultural Heritage 中國非物質文化遺數字博物館. I-188. Available online: http:/ / www.ihchina.cn/Article/Index/detail?id=12366 (accessed on 29 September 2021).

Ding, Zhulan 丁築蘭. 2014. Cong Yalu wang kan miaozu xungen yishi jiqi shengtai yiyi 從亞魯王看苗族尋根意識及其生態意義 [The Miao Ethnic Group's Search for Roots and Its Ecological Meaning as Seen from Yalu wang]. Journal of Guizhou Education University 11: 23-26.

Douglas, Mary. 2001. Purity and Danger: An Analysis of Concepts of Pollution and Taboo. London: Routledge.

Fischer-Lichte, Erika. 2008. The Transformative Power of Performance: A New Aesthetics. Translated by Saskya Iris Jain. London: Routledge.

Gao, Hehong 高荷紅. 2014. Yalu wang geshi koushushi yanjiu 亞魯王歌師口述史研究 [Research on the Oral History of Dongb Langf for Yalu wang]. In Collected Literary Criticisms of Yalu wang. Edited by Weiren Yu. Beijing: China Literature and History Press, vol. 2, pp. 355-74.

Goffman, Erving. 1959. The Presentation of Self in Everyday Life. New York: Doubleday.

Goody, Jack. 2010. Myth, Ritual and the Oral. Cambridge: Cambridge University Press.

Kertzer, David I. 1988. Ritual, Politics, and Power. New Haven: Yale University Press.

Li, Zhiyong 李志勇. 2011a. Mazong geshi Yang Baoan koushushi 馬宗歌師楊保安口述史 [Oral History of Dongb Langf Yang Baoan in Mazong]. In Collected Literary Criticisms of Yalu wang. Edited by Weiren Yu. Beijing: China Literature and History Press, vol. 1, pp. 173-87.

Li, Zhiyong 李志勇. 2011b. Dagong geshi Yang Guangxiang koushushi 打供歌師楊光祥口述史 [Oral History of Dongb Langf Yang Guangxiang in Dagong]. In Collected Literary Criticisms of Yalu wang. Edited by Yu Weiren. Beijing: China Literature and History Press, vol. 1, pp. 272-85.

Ma, Yongbin 麻勇斌. 2014. Yalu wang changsong yishi yunhan de Miaozu gudai buzu guojia lizhi zixun jiexi 亞魯王唱誦儀式藴含的苗 族古代部族國家禮制資訊解析 [The Ritual of Ancient Tribal State of the Miao Ethnic Group in the Oral Performance of Yalu wang]. Guizhou Social Sciences 2: 92-97. 
Malinowski, Bronislaw. 1948a. Magic, Science, and Religion. In Magic, Science and Religion and Other Essays. Edited by Robert Redfield. Glencoe, IL: The Free Press, pp. 1-71.

Malinowski, Bronislaw. 1948b. Myth in Primitive Psychology. In Magic, Science and Religion and Other Essays. Edited by Robert Redfield. Glencoe: The Free Press, pp. 72-124.

Schechner, Richard. 1993. The Future of Ritual: Writings on Culture and Performance. London: Routledge.

Tang, Na 唐娜, and Zhiyao Ma 馬知遙. 2015. Xibu Miaozu shishi Yalu wang chuanchengren Chen Xinghua koushushi 西部苗族史詩亞 魯王傳承人陳興華口述史 [Oral History of Chen Xinghua, Inheritor of the Hero Epic Yalu wang of Western-Dialect Miao Ethnic Group]. Folk Culture Forum 3: 68-73.

Tang, Na 唐娜. 2010. Guizhou Mashan Miaozu yingxiong shishi Yalu wang kaocha baogao 貴州麻山苗族英雄史詩亞鲁王考察報告 [A Survey Report of the Heroic Epic Yalu wang of the Miao Ethnic Group in Mashan]. Folk Culture Forum 2: 88-99.

Tang, Na 唐娜. 2012. Tan Yalu wang yanshuren donglang de chuancheng jizhi yu shengtai 談亞魯王演述人東郎的傳承機制與生態 [The Mechanism and Ecology of the Inheritance of Dongb Langf, Yalu wang's Oral Performer]. Folk Culture Forum 4: 48-56.

Tönnies, Ferdinand. 2001. Community and Civil Society. Edited by Jose Harris. Translated by Margaret Hollis. Cambridge: Cambridge University Press.

Wang, Jinyuan 王金元. 2011a. Ziyunxian Sidazhaixiang Menglincun Miaozu sangzang yishi diaocha baogao 紫雲縣四大寨猛林村苗族 培葬儀式調報告 [A Survey Report on the Funeral Ritual of the Miao Ethnic Group in Menglin Village, Sidazhai, Ziyun County]. In Collected Literary Criticisms of Yalu wang. Edited by Weiren Yu. Beijing: China Literature and History Press, vol. 1, pp. 148-69.

Wang, Jinyuan 王金元. 2011b. Sidazhai geshi Wei Zhengrong koushushi 四大寨歌師韋正榮口述史 [Oral History of Dongb Langf Wei Zhengrong in Sidazhai]. In Collected Literary Criticisms of Yalu wang. Edited by Weiren Yu. Beijing: China Literature and History Press, vol. 1, pp. 286-309.

Wu, Xiaodong 曉東. 2012. Yalu wang mingcheng yu xingcheng shijian kao 亞魯王名稱與形成時間考 [A Study of Yalu wang's Name and Time of Formation]. Folk Culture Forum 4: 34-40.

Xiong, Zha Blong, Malina Her, Mai Kao Xiong, Wa Houa Vue, Cher Teng Yang, Nao Houa Moua, Nao Khue Yang, and Wangsue Lee. 2020. Exploring Hmong Americans' Attitudes towards Hmong Traditional Full-Service Funerals: The Hmong Cultural Integration Project. Hmong Studies Journal 22: 1-38.

Xu, Xinjian 徐新建. 2014. Shengsi liangjie songhunge: Yalu wang yanjiu de jige wenti 生死兩界送魂歌: 亞魯王研究的幾個問題 [Requiem of this World and the World After: Several Questions on the Study of Yalu wang]. Studies of Ethnic Literature 1: 74-90.

Xu, Yuting 徐玉挺. 2011a. Zongdixiang Gebacun Miaozu sangzang xisu diaocha baogao 宗地戈村苗族培葬習俗調報告 [A Survey Report on the Funeral Customs of the Miao Ethnic Group in Geba Village, Zongdi County]. In Collected Literary Criticisms of Yalu wang. Edited by Weiren Yu. Beijing: China Literature and History Press, vol. 1, pp. 135-47.

Xu, Yuting 徐玉挺. 2011b. Geran geshi Liang Darong koushushi 格然歌師梁大榮口述史 [Oral History of Dongb Langf Yang Darong in Geran]. In Collected Literary Criticisms of Yalu wang. Edited by Weiren Yu. Beijing: China Literature and History Press, vol. 1, pp. 257-71.

Yang, Chunyan 楊春豐. 2011. Bamaozhai geshi Huang Laohua koushushi 巴茅寨歌師老華口述史 [Oral History of Dongb Langf Huang Laohua in Bamao]. In Collected Literary Criticisms of Yalu wang. Edited by Weiren Yu. Beijing: China Literature and History Press, vol. 1, pp. 239-56.

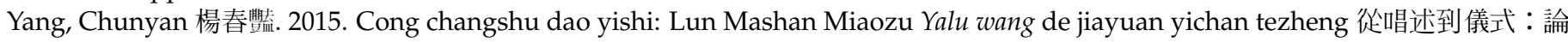
麻山苗族亞魯王的家園遺特 [From Oral Performance to Ritual: On Yalu wang's Feature of Hometown Legacy]. Journal of Baise University 4: 76-82.

Yang, Lan 楊蘭. 2014. Qiantan Yalu wang de chuancheng fangshi jiqi shehui gongneng 淺談亞魯王的傅承方式及其社會功能 [On the Means of Inheritance and Social Functions of Yalu wang]. In Collected Literary Criticisms of Yalu wang. Edited by Yu Weiren. Beijing: China Literature and History Press, vol. 2, pp. 236-47.

Yang, Liu 楊柳. 2016. Shengming de yinchang: Yalu wang shixing yiyun qianxi 生命的吟唱：亞魯王詩性意蘊淺析 [Chanting of Life: Poetic Connotations of Yalu wang]. Beijing Folklore Forum 1: 143-50.

Yu, Weiren 余未人, ed. 2011. Yalu wang wenlun ji 亞魯王文論集 [Collected Literary Criticisms of Yalu wang]. Beijing: China Literature and History Press, vol. 1.

Yu, Weiren 余未人. 2014. Yalu wang de minjian Xinyang tese 亞魯王的民間信仰特色 [Yalu wang's Features of Folk Belief]. In Collected Literary Criticisms of Yalu wang. Beijing: China Literature and History Press, vol. 2, pp. 302-16.

Yue, Sheng 越聲. 2019. Shenmeyang de gaibian keyi daibiao Miaozu? 什麼樣的改編可以代表苗族? [What Can Represent the Miao Ethnic Group?]. China Arts News, January 18.

Zhang, Ying 張穎, and Zhaorong Peng 彭兆榮. 2013. Jia zai nian zhong: Guojiaji feiwuzhi wenhua yichan Yalu wang de renzhi yu chanshi 家在念中：國家級非物質文化遺亞魯王的認知與闡釋 [Hometown in Belief: On the National Intangible Cultural Heritage Yalu wang]. Guizhou Social Sciences 11: 82-86.

Zhao, Xiaohuan. 2013. Political Uses of Wugu Sorcery in Imperial China: A Cross-Cultural Perspective. Magic, Ritual, and Witchcraft 8: 132-61. [CrossRef] 